\title{
夏季と冬季における名古屋の都市気候観測調査 FIELD OBSERVATIONS ON URBAN CLIMATE OF NAGOYA IN SUMMER AND WINTER
}

\author{
菊池 信*, 堀越哲美** \\ Makoto KIKUCHI and Tetsumi HORIKOSHI
}

\begin{abstract}
The objective of this study is to clarify the urban climate related to the human living environment and to obtain the basic information to apply to urban planning in Nagoya. Field observations were conducted in summer and winter, from 2000 to 2001. Air temperature, humidity, wind direction and velocity were measured in mobile observation points. Consequently, 1)In the early morning of the summer and winter, lower temperature occurred in the parts of western suburb of Nagoya and on the eastern hills area. Higher temperature occurred around the bay area and in the center of the city. 2)In the daytime of the summer, sea breeze blow from bay area to the inland. Lower temperature also occurred in the western part and bay area. Higher temperature occurred in the center of the city. 3)In the daytime of the winter, there was no defference of temperature over the city, because the storong northwestern wind(Ibukioroshi) prevailed. 4)In the evening of the summer, lower temperature occurred on the eastern hills area. Higher temperature occurred in the center area. 5)When the wind was calm in winter evening, heat island clearly appered in Nagoya.
\end{abstract}

Keywords : Urban climate, Temperature, Prevailed wind, The center of the city, Suburb 都市気候, 気温, 卓越風, 都心, 郊外

\section{1.はじめに}

都市気候の抑制や予測に際し、基礎資料となる気候環境の実測によ る把握は欠くことのできないものである。特に既存の観測システムで はつかみ得ないような地表面付近の生活域のデー夕取得は重要である と考えられる。それは近年発達してきた数值シュミレーションの妥当 性の検討や屋外の都市空間の襄境調節や市街地整備、緑地効果の把握 の設計資料に利用できるものである。都市気候の研究は古くから 数多くなされているが名古屋に関する研究は必ずしも多くないい 2)。名古屋における都市気候に関する実測による研究としては、 大和田 ${ }^{3) 4)}$ による名古屋の栄を中心とした比較的狭い都市域を対象 としているもの、濃尾平野全般にわたる広域の研究があり、名古 屋市の河川沿いの風の道に関する実測研究5)677)8９）がある。しか し、観測域が限られているという制約がある。そこで、本研究に おいては名古屋の市街地について、地表面付近の高さにおいて人 間の活動が行なわれる生活域における夏季・冬季における気候環 境の実態を知り、日射遮蔽やみどりの被覆等の都市の屋外熱環境 の調節・計画に資する基礎データを得ようとすることを目的とす る。

都市気候の実測デー夕は、様々な変化の様相を呈するので、同時多 点観測が望ましい。しかし、測定器や測定点の確保など経済的・物理
的に実現は容易ではないた め、従来より用いられてき た移動観測を行なうことと し、それらのデータをより 汎用的に位置づけるために、 背景となる気圧配置の基づ く総観気象場を把握するこ ととした。

\section{2. 観測概要}

図 1 に観測地域を示す。観 測範囲を名古屋の都市域を 中心として、地形的に変化 していると考えられる天白 川及び庄内川と東部の丘陵 周辺に囲まれた地域とした。 観測地域の地形は、庄内川 の河口付近と中川運河の間 に沖積層 (海抜 $0 \mathrm{~m}$ 以下) 、東 部の丘陵に第 3 紀層・第 4 紀

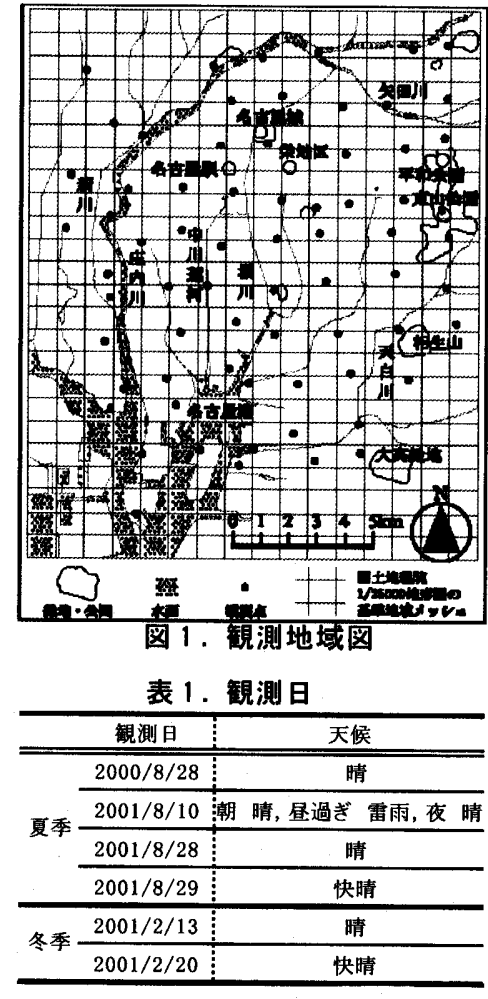

Japan Railway Construction, Transport and Technology Agency, M. Eng. Prof., Department of Environmental Technology \& Urban Planning, Nagoya Institute of Technology, Dr. Eng.
* 独立行政法人鉄道建設・運輸施設整備支援機構 工修 名古屋工業大学大学院都市循環システム工学専攻 教授・ 工博 
層洪積層（標高 $60 \sim 80 \mathrm{~m}$ )、その間の地域に沖積層（海抜 $0 \mathrm{~m}$ 以上） から第 4 紀層洪積層（標高 $10 \sim 15 \mathrm{~m}$ ) の地域が広がっている。生活 域の気候を調べるため高度による補正は行なっていない。図中の メッシュは国土地理院 $1 / 25000$ 地形図の基準地域メッシュ、黒い 点は観測点を表す。観測点はメッシュ内で幹線道路を避けその土 地利用状況を最も反映していると判断している地点を選定し、そ の中から日当たりがよく風の障害となるものが少ない地点を選定 した。すべての観測点はアスファルト舗装面上としその内多数の 点は道路交差点であるが、既報の論文において河川上を海風が吹 走するなどの現象が観測されているので河川に架かる橋にも観測 点を設けた。また、気温や風が連綍的に変化すると仮定した密 度・距離を保持しながら隣のメッシュ同士で土地利用形態の類似 している場合は統合し、観測時間短縮と観測点数増加のバランス を計った。なおこれらの判断の根拠のひとつとして名古屋緑の現 況調査報告（H12 年度）に基づき作成した緑被率を図 2 に示す。商 業施設が集まっている名古屋駅や栄付近は緑被率が $0 \%$ から $20 \%$ で あり、名古屋城などの緑地公園が存在する場所は $40 \%$ 前後と高く なっている。東部丘陵地帯や庄内川以西では $40 \%$ 以上の地域が多 くなっている。観測点数を定点 1 点 (名古屋市御器所町内) と移動 観測点 68 点の計 69 点とした。

観測は表 1 に示すとおり 2000 年 8 月から 2001 年 8 月の夏季と冬 季に行なった。定点において温度・湿度・日射量、移動観測点に おいて温度・湿度・風向・風速を観測項目とした。アスマン通風 乾湿計は乾球温度と湿球温度を測定し、ビラム式風向風速計はビ ラム回転数から風程を求め風速を計算した。風向は矢羽根の指示 方位を目視して観測した。ネオ日射計は電圧計にて出力電圧を測 定し日射量に変換した。測定高さはアスマン通風乾湿計に関して 地上 $90 \mathrm{~cm}$ 、ビラム式風向風速計は地上 $150 \mathrm{~cm}$ である。観测時間に ついては、定点にて 0:00〜 24:00まで 30 分毎に計測し、移動観 測の時間帯は 5 分毎に計測した。移動観測を $3: 30 \sim 12: 30 \sim$ と $20: 30 \sim の 1$ 日 3 回行ない、観測点をいくつかのコースに分けて 観測時間が 2 時間に納まるように計画し、観測地点での測定時間 は従来の測定経験から 3 分間として自動車から降りて観測をし た。移動観測については定点での観測により時刻補正 ${ }^{10)}$ を行なつ たが、風に関しては定点での風速が大きい変化がみられなかった ことと、風向に関しては補正精度及び前述の研究例等を鑑みて行 なっていない。本研究では、時々刻々の変化である気象学的な様 相を観測するのではなくて、ある時間内の平均的な状況である気 候を把握することを主眼として上述の補正処理を行なった。

\section{3. 気圧配置と定点の日变動}

いかなる状況のもとで観測を行なったかを気候学的に整理すること は都市気候の基礎資料として、本研究の考察を行なう上で有意である と考えられる。日本付近を中心とした東アジアの気圧配置は大きく分 けて 6 つの型に分類され、吉野・福岡 ${ }^{11)}$ の分類基準に基づいて観測日 の気圧配置を考察した。2000 年 8 月 28 日は、午前 9 時の気圧配置にお いて東から張り出した高気圧が本州を覆い、中心気圧 $985 \mathrm{hPa}$ の台風が 北緯 25 度・東経 130 度付近に位置していたため、夏型（V型）から台 風型 (VI型) への移行上と考えられるが、30日に至っても北緯 30 度を 越えていないことから28 日においては高気圧の影響下にあった

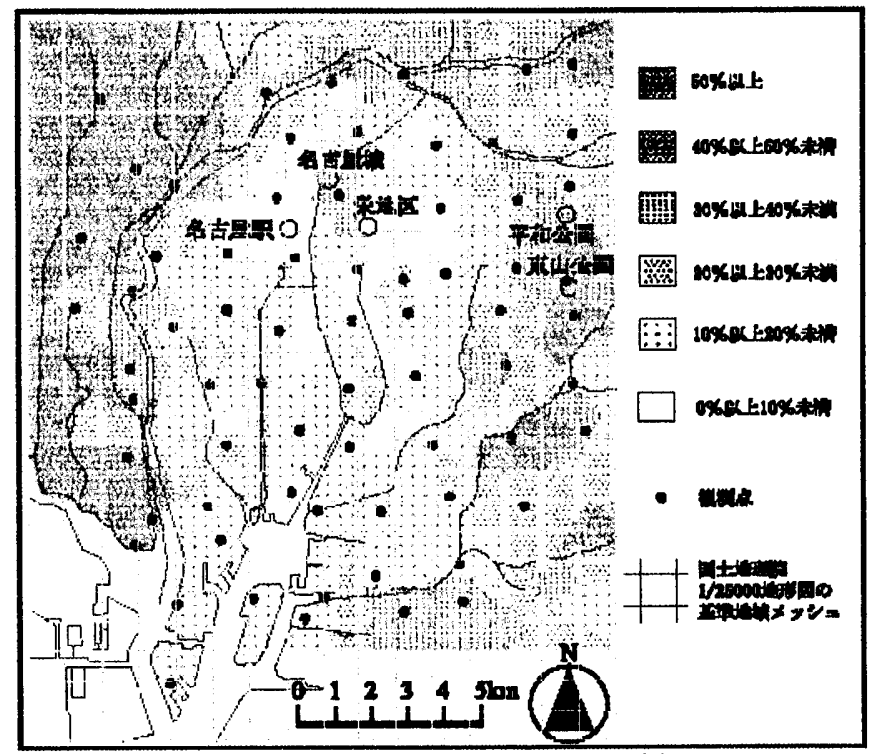

図 2. 名古屋の緑被率（H12 年度）

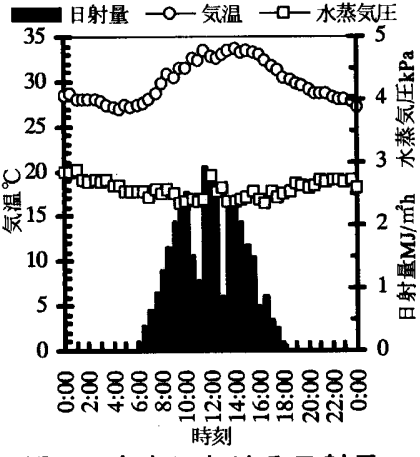

图 3.定点における日射量。 気温と水蒸気圧变化 (2000年8月 28 日)

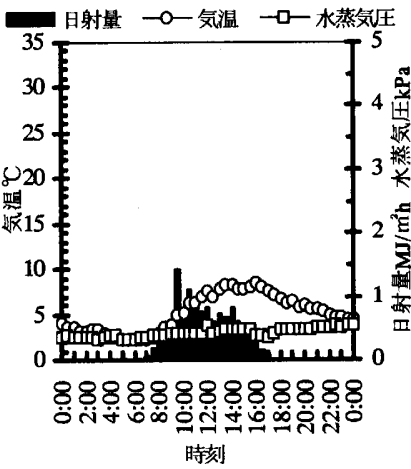

図 5。定点における日射量、 気温と水蒸気压变化 (2001年 2 月 13 日)

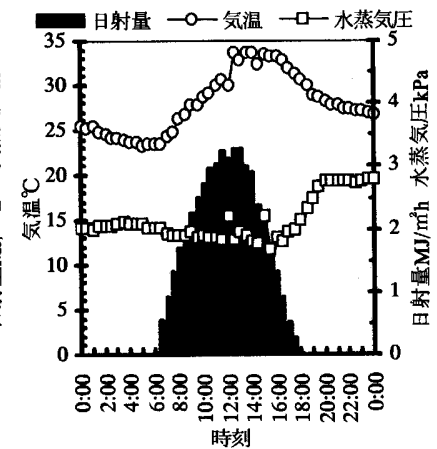

図 4，定点における日射量、 気温と水蒸気压变化 (2001年8月 29 日)

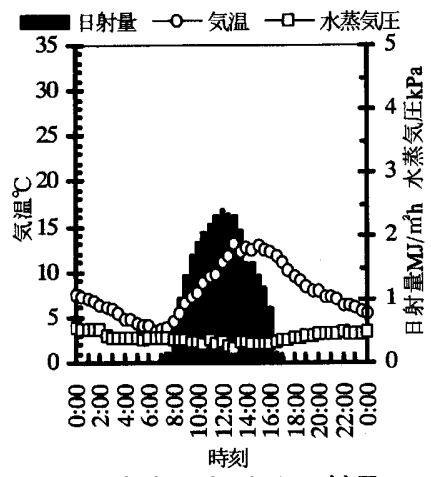

図 6。定点における日射量

気温と水蒸気圧変化 (2001年 2 月 20 日)
夏日と推察される。2001 年 8 月 29 日は、午前 9 時の気圧配置にお いて、大陸の高気圧と北緯 50 度・東経 145 度付近に存在した中心 気圧 $985 \mathrm{hPa}$ の台風に挟まれ、等圧線は緩やかに傾斜していたが、 前線はみられなかった。2 日後の 31 日には台風が北緯 30 度付近 まで北上し、伴うように西側から前線が流入してきた。台風型 (VI型) の前兆と考えられる。2001 年 2 月 13 日は、大陸からの優 勢な高気圧が張り出し、低気圧が才ホーツク海上に抜け、等圧線 がやや広がった縦縞模様であったため、典型的な冬型気圧配置の 西高東低型（I 型）の終端時期と考えられる。2001 年 2 月 20 日 は、発達した低気圧がオホーツク海上へ抜け、大陸から張り出し 
た高気圧が日本列島を覆い、 翌 21 日にはセル状となった高 気圧が日本列島を通過したた め、西高東低型（Ｉ型）よりむ しろ移動性高気圧型（III 型）と 考えられる。

上述のような気圧配置で あった各観測日の定点におけ る結果を図3-図 6 に示す。 8 月 28 日において、日射量は $11: 30$ $\sim 12: 30$ の間 $2.6 \mathrm{MJ} / \mathrm{m}^{2} \mathrm{~h}$ 以上で あった。最高気温は $14: 00$ に $33.7^{\circ} \mathrm{C}$ 、最低気温は $4: 30$ に 27 ${ }^{\circ} \mathrm{C}$ であった。水蒸気圧は $2.5 \mathrm{kPa}$ 前後で 1 日を通して大きな変化 はみられなかった。 8 月 29 日に おいて、日射量は 10:00 14: 00 の間 $2.7 \mathrm{MJ} / \mathrm{m}^{2} \mathrm{~h}$ 以上であっ た。気温は $12: 00$ に $30.1^{\circ} \mathrm{Cから}$ $12: 30$ に $33.8^{\circ} \mathrm{C}$ へ急激に変化 し、最高気温は $12: 30 に 33.8^{\circ} \mathrm{C}$ 、 最低気温は $5: 00$ に $23.3{ }^{\circ} \mathrm{C}$ で あった。水蒸気圧は 18:00まで $2.0 \mathrm{kPa}$ 前後であったが、その後 $20: 00$ には $2.8 \mathrm{kPa}$ まで上昇し安 定している。朝 4:00 と昼 14:00 の風の分布（図 17 及び図 20）に 風向の変化があらわれている ように、気温と水蒸気圧の変 化に風の影響がうかがえる。2 月 13 日において、日射量は日中 でも $0.8 \mathrm{MJ} / \mathrm{m}^{2} \mathrm{~h}$ と少なかった。 最高気温は $16: 00$ に $8.4^{\circ} \mathrm{C}$ 、最 低気温は $6: 00$ に $2.2{ }^{\circ} \mathrm{C}$ であっ た。水蒸気圧は $0.4 \mathrm{kPa}$ 前後で 1 日を通して大きな変化はみら れなかった。2月 20 日において、
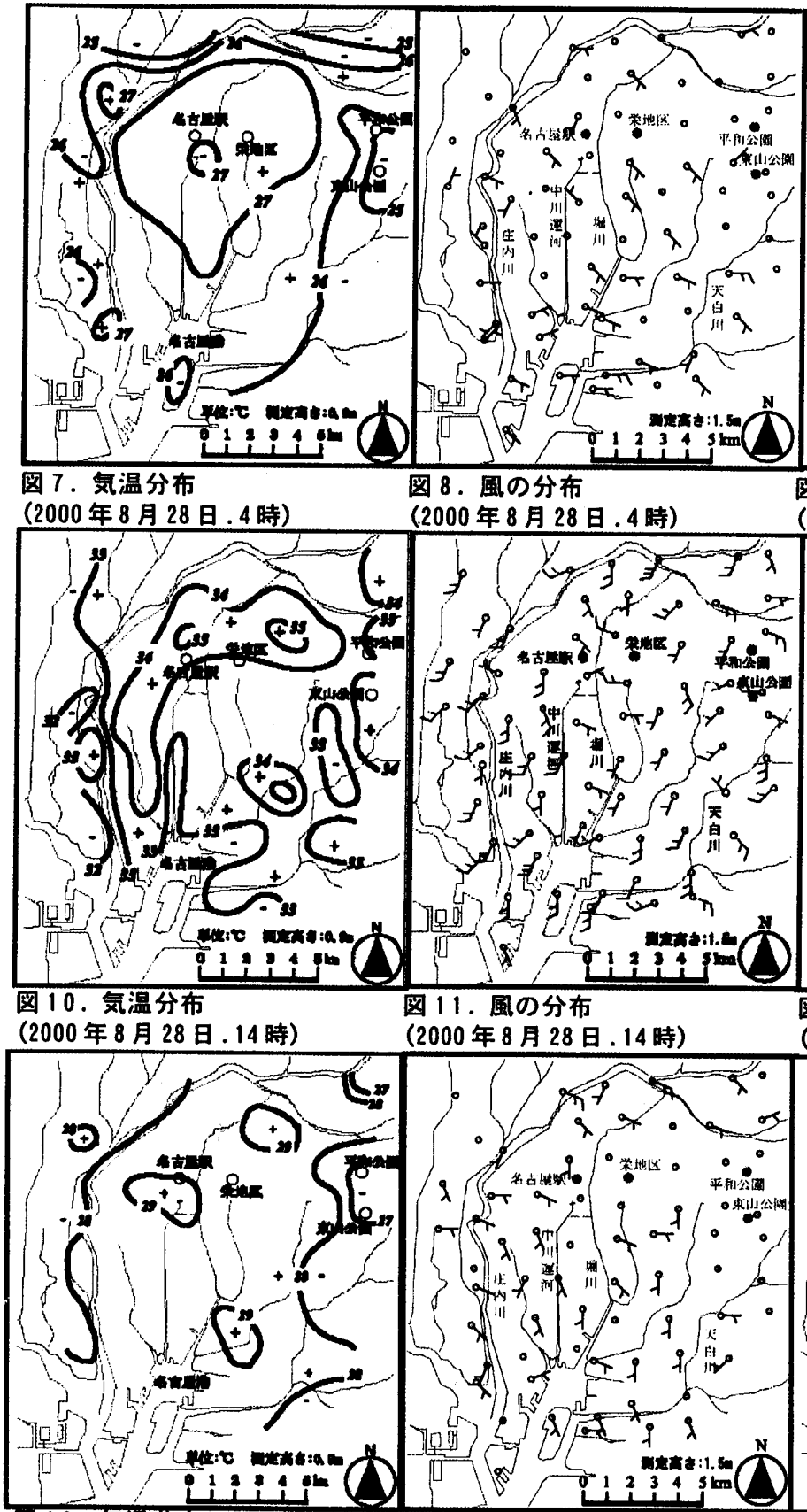

図13.気温分布

(2000年 8 月 28 日. 21 時)

日射量は $10: 30 \sim 13: 30$ の間 $2.0 \mathrm{MJ} / \mathrm{m}^{2} \mathrm{~h}$ 以上であった。最高気温 は $13: 00$ に $13.2^{\circ} \mathrm{C}$ 、最低気温は $6: 30 に 3.4^{\circ} \mathrm{C}$ であった。水蒸気圧 は $0.4 \mathrm{kPa}$ 前後で 1 日を通して大きな変化はみられなかった。

\section{4. 夏季の気候分布}

\subsection{0 年 8 月. 28 日の結果}

1) 早朝の気温 (図 7) 名古屋駅と栄を中心とした地域に $27^{\circ} \mathrm{C}$ 以 上の高温域がみられ、そこから周辺へしだいに低くなっていた。 東部丘陵の東山公園の辺りと北部は $26^{\circ} \mathrm{C}$ 以下の温度域が形成され ていた。

2）早朝の風（図 8）弱い南東寄りの風が全般的にみられた。東部 丘陵の緑地とその西側に静稳域がみられた。名古屋駅と栄を中心 とした地域も静櫯であった。
图14.風の分布

(2000年8月 28 日. 21 時) 西部の庄内川流域において高かった。 $4{ }^{\circ} \mathrm{C}$ であった。
図 8. 風の分布 (2000年8月28日.4時)

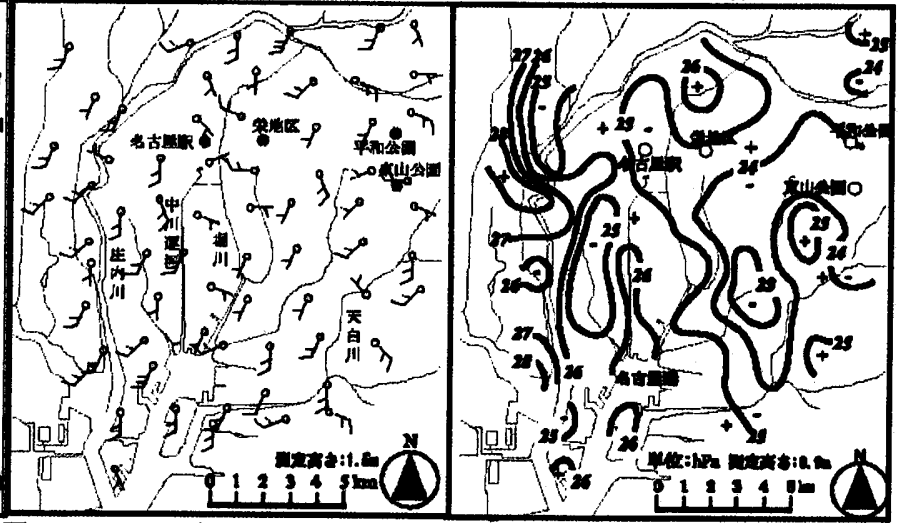

图11. 風の分布

(2000年8月28日.14 時)

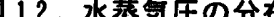
(2000年8月 28 日. 14 時)
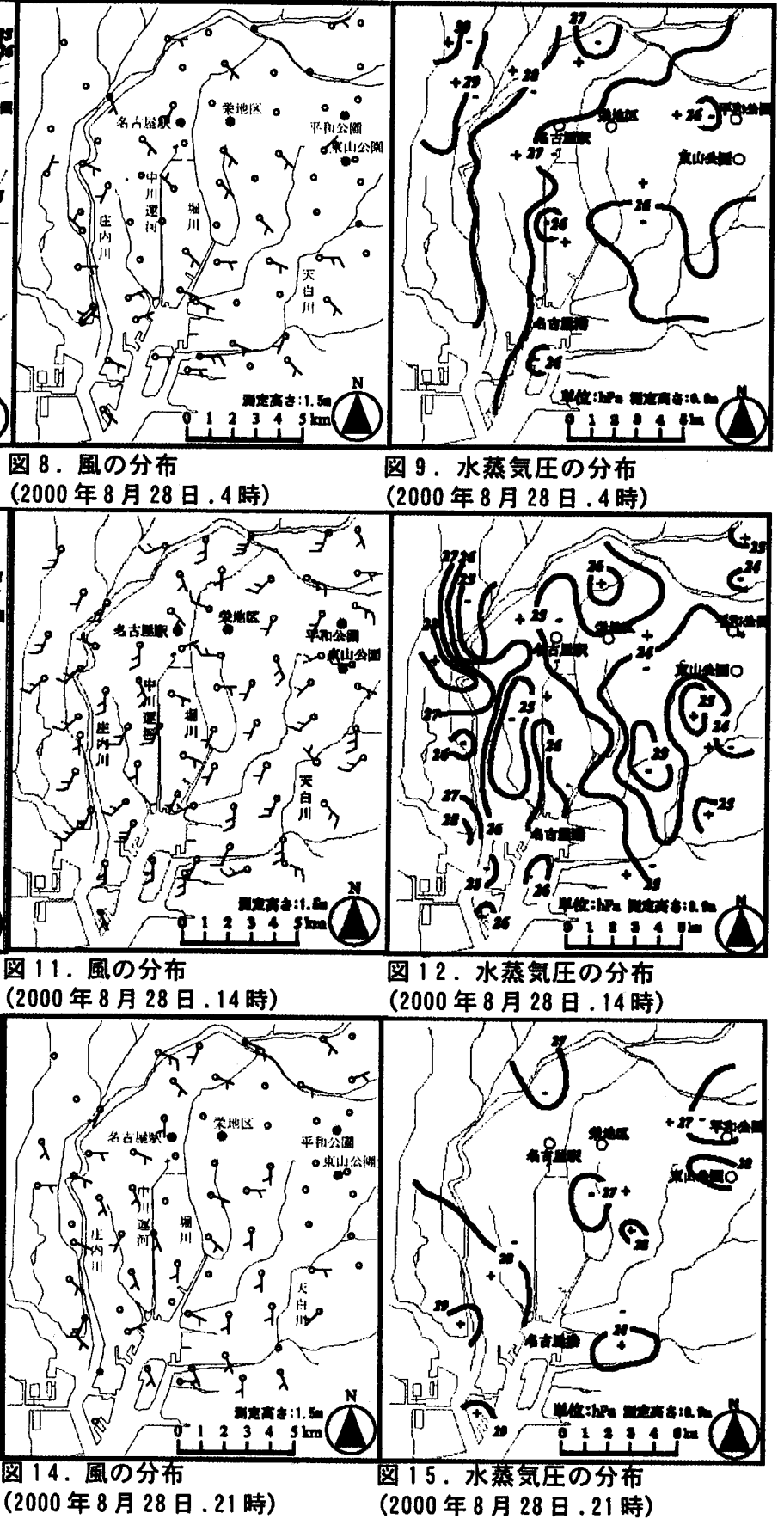

图 9. 水蒸気圧の分布 (2000年8月28日.4 時)

3）早朝の水蒸気圧（図 9) 水蒸気圧は $25 \mathrm{hPa}$ から $30 \mathrm{hPa} に$ 分布し、

4) 日中の気温（図 10）観測地域全体が $31^{\circ} \mathrm{C}$ 以上の分布であった。 $34{ }^{\circ} \mathrm{C}$ 以上の地域は栄地区や名古屋駅の北、東山公園の周辺、山崎 川の中流付近であった。 $32{ }^{\circ} \mathrm{C}$ 以下の地域は庄内川の流域と中川運 河の観測点であった。中川運河の観測点は運河にかかる橋の上に て計測を行なった。都市域より相対的に温度の低い南寄りの風が 卓越していたことから、都市部の比較的暖かい空気が北へ押し上 げられたと考えられる。この範囲内でのヒートアイランド強度は

5）日中の風（図 11） 全域で南寄りの風が観測されたが、東部丘 陵の地域は南寄りの風が卓越せず、名古屋駅と栄を中心とした地 域は周辺地域と比べて風が弱くなっていた。また中川運河などの 


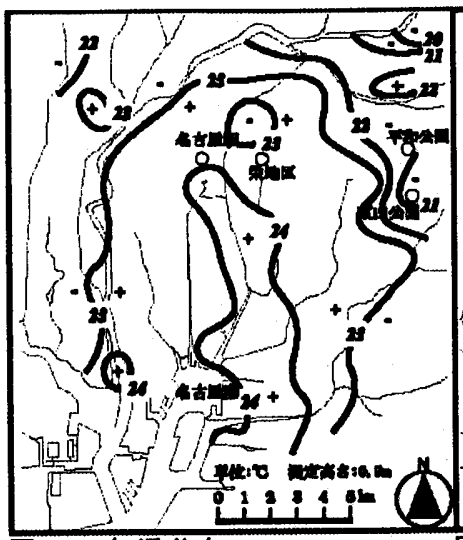

图16. 気温分布

(2001年8月29日.4時)

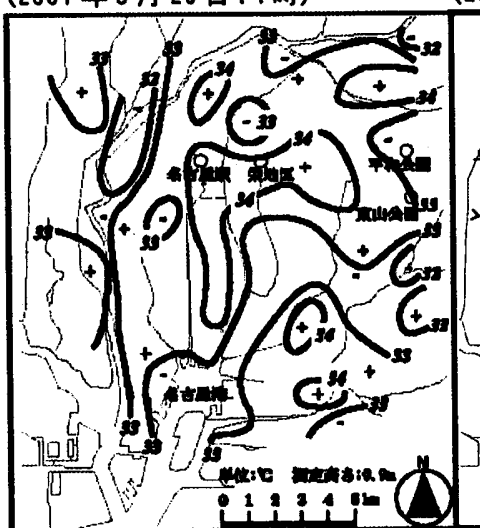

图19. 気温分布

(2001年8月29日.14時)

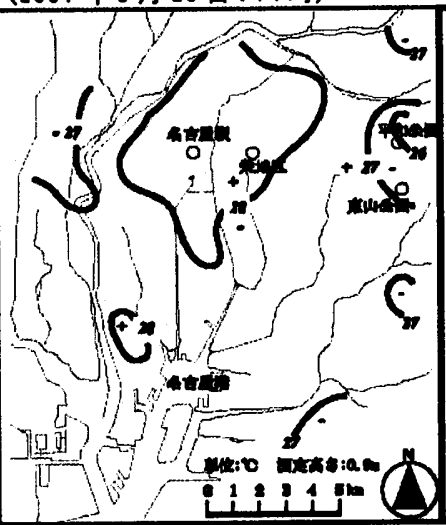

図22. 気温分布

(2001年8月29日.21時)

図 23 . 風の分布

(2001年8月 29 日. 21 時)

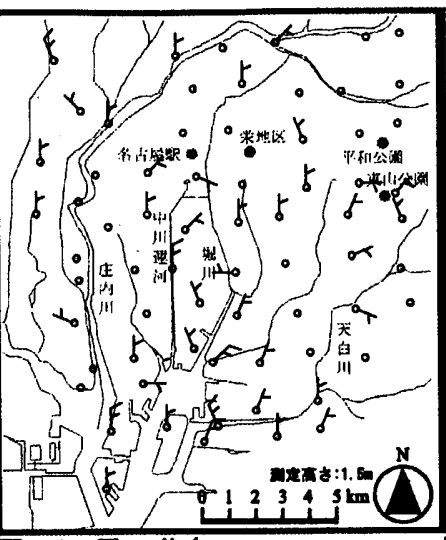

图 17. 風の分布

(2001年 8月 29日. 4 時) (2001年8月29日.14時)

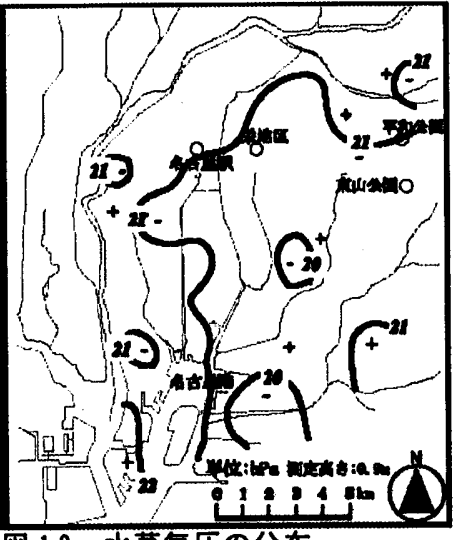

图 18 . 水蒸気压の分布

(2001年8月29日.4時)

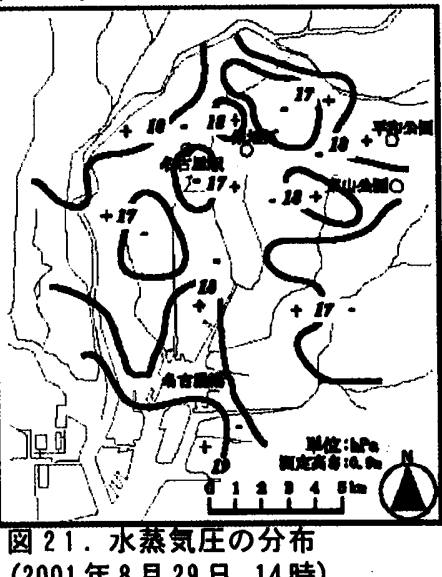

(2001年8月 29日.14時)

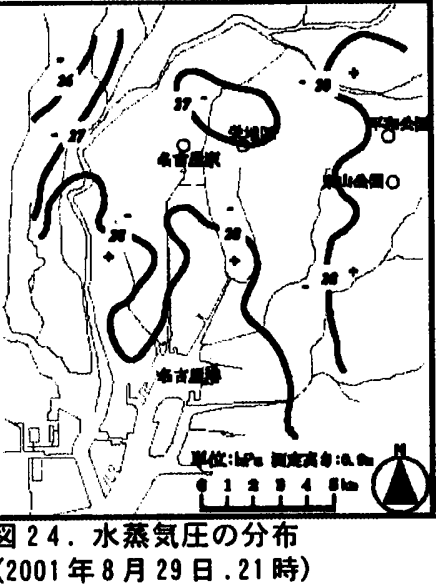

4.22001 年 8 月 29 日の結果

1) 早朝の気温 (図 16) 名古屋 港東側から北へ向かって $24^{\circ} \mathrm{C}$ 以 上の高温域が現れ、そこから周 辺へしだいに低くなっていた。 東山公園を含めて北東部は $22^{\circ} \mathrm{C}$ 以下の温度域が形成され、名古 屋城付近で $23^{\circ} \mathrm{C}$ 以下のクールス ポットがみられた。ヒートアイ

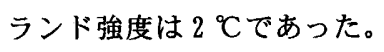

2）早朝の風（図 17）弱い北奇 りの風が観測されたが、東部丘 陵の北部や南部、生内川流域に は静稳域がみられた。名古屋駅 と栄を中心とした地域も静穞域 であった。

3) 早朝の水蒸気圧 (図 18) 水 蒸気圧は、 $21 \mathrm{hPa}$ 前後のほぼ一 様な分布であった。

4) 日中の気温 (図 19) 観測地 域のほほ全域が $33^{\circ} \mathrm{C}$ 以上の高温 域となり、ところどころクール スポットがあらわれた。名古屋 城一体はまとまった緑地帯のた めクールスポットとなっている と考えられる。2000年 8 月 28 日 の昼の気温分布と類似して高温 域が名古屋駅や栄を中心とした 地域、山崎川の中流付近に出現 した。

5）日中の風（図 20）朝と比較 して風向に変化がみられ、西部 において西寄り、海岸部におい て南西寄りであった。しかしな がら、名古屋駅や栄を中心とし た地域、東山公園などの東部の 丘陵地域は、静穏な傾向がうか

がえる。2000 年 8 月 28 日とくらべて、海風が名古屋駅や栄を中 心とした地域まで侵入していないため、気温分布における高温域 が北へそれほど押し上げられていないと考えられる。さらに西側 のクールスポットは郊外からの吹き込み、海岸部は海風の流入と 考えられる。

6) 日中の水蒸気圧 (図 21 ) 水蒸気圧は $18 \mathrm{hPa}$ 以下の分布が広 がっていた。海岸部と観測地域の北部に $19 \mathrm{hP}$ a 以上の高い地域が 現れた。

7) 夜間の気温 (図 22) 名古屋駅と栄の都心部は $28^{\circ} \mathrm{C}$ 以上の相対 的に気温の高い地域であった。東部丘陵や北西部は $27^{\circ} \mathrm{C}$ 以下の相 対的に気温の低い地域であった。

8) 夜間の風（図 23 ）穞やかな南寄りの風が都心部の付近まで吹 き込んでいた。 
9）夜間の水蒸気圧（図 24）南よ りの風が吹き込んでいた地域は ほぼ $28 \mathrm{hPa}$ 前後であった。都心部 と北西部は $27 \mathrm{hPa}$ 以下の低い地域 であった。

\section{5. 冬季の気候分布}

5.12001 年 2 月 13 日の結果

1）早朝の気温（図 25） $2{ }^{\circ} \mathrm{C}$ 以上の 地域が名古屋港から栄地区へ向 かって広がっていた。東部丘陵 の東山公園付近と北部は $1.5{ }^{\circ} \mathrm{C}$ 以 下の示度で、観測地域の周辺に 低温域があらわれている。

2）早朝の風（図 26）庄内川流域 と海岸部において北寄りの風が 吹いていた。名古屋駅と栄を中 心とした地域は静稳な傾向がう かがえる。

3）早朝の水蒸気圧（図 27）水蒸 気圧は $3 \mathrm{hPa}$ から $5 \mathrm{hPa}$ のほぼ一様 な分布であった。西部の庄内川 流域において高く $4 \mathrm{~h} \mathrm{P} \mathrm{a} \mathrm{以上で}$ あった。

4) 日中の気温 (図 28) ほほ一様

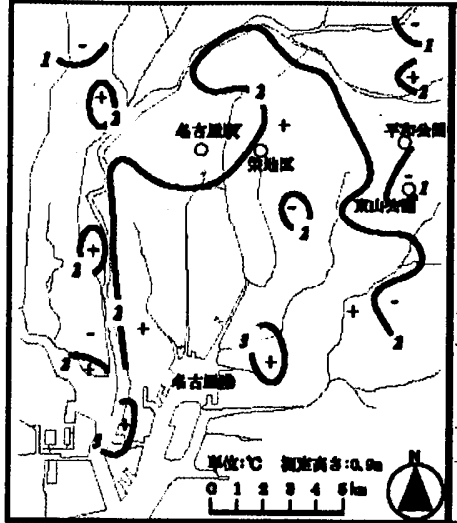

图25.気温の分布 (2001年 2月13日.4時)

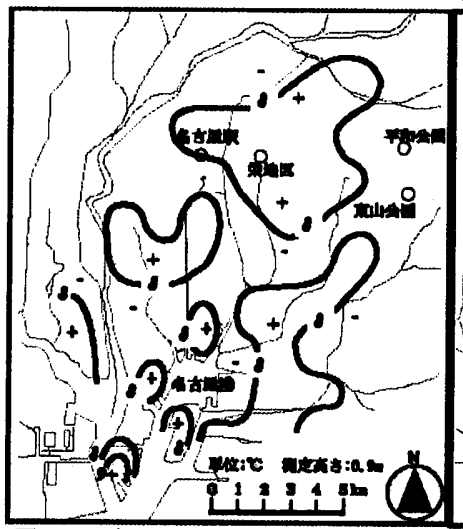

図 28. 気温の分布
(2001 年 2 月 13 日.14 時)

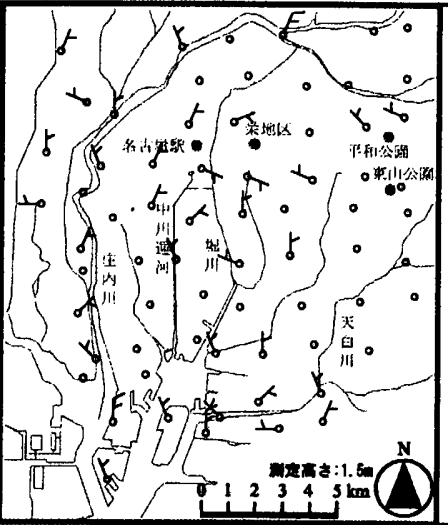

图26.風の分布 (2001年 2 月 13 日. 4 時)

図 27 . 水蒸媱圧の分布 (2001年2月13日.4時)

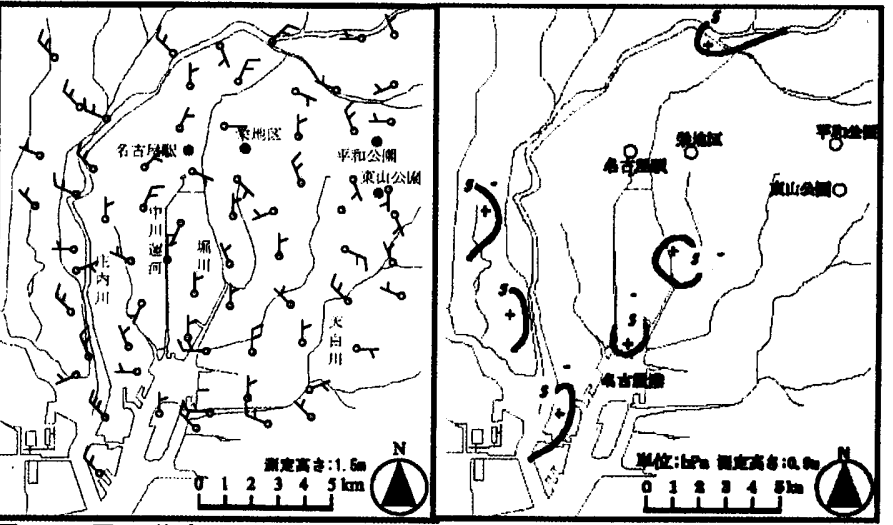

図29. 風の分布 (2001年2月13日.14時)

水蒸気压の分布 (2001年 2 月 13 日. 14 時)

な $7.5{ }^{\circ} \mathrm{C}$ から $8.5{ }^{\circ} \mathrm{C}$ の分布であっ た。 $8.5{ }^{\circ} \mathrm{C}$ 以上の地域は港の埋立 地であった。

5）日中の風（図 29）庄内川流域 と海岸部において北西の風が卓 越していた。栄を中心とした地 域や東山公園の周辺は静穏であ る。朝や夜と比べて風が強く、そ のため気温分布は小さくなった と考えられる。

6) 日中の水蒸気圧 (図 30 ) 水蒸 気圧は庄内川流域、堀川流域、海

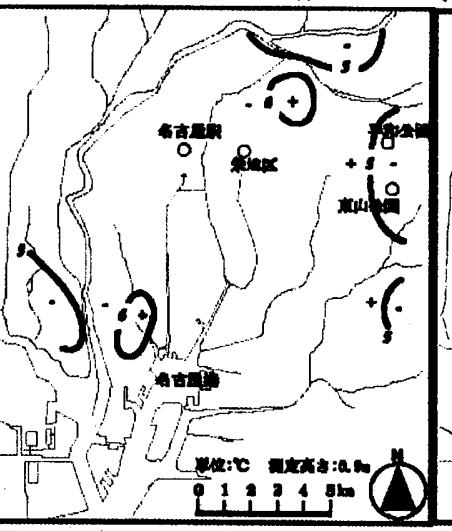

図 31．気温の分布

(2001年 2 月 13 日. 21 時)

岸部において局所的に高い地域が現れ、水辺と地形的影響である と考えられる。しかしながら、大体は $5 \mathrm{hP} \mathrm{a}$ 前後の一様な分布で あった。

7) 夜間の気温（図 31 ） $5{ }^{\circ} \mathrm{C}$ から $6{ }^{\circ} \mathrm{C}$ のぼ一様な分布であった。 東部丘陵の緑地帯は $5{ }^{\circ} \mathrm{C}$ 以下の相対的にやや低い地域であった。 8 ）夜間の風（図 32 ）都心部や東部丘陵の地域では風向が一定で はないが、他の地域では北西よりの風が吹いているようにうかが える。
9）夜間の水蒸気圧（図 33 ） 日中と同様 $5 \mathrm{hPa}$ 前後の一様な分布で あった。

\subsection{1 年 2 月 20 日の結果}

1）朝 4:00 の気温（図 34）観測地域の南東部から北西へ向かうに

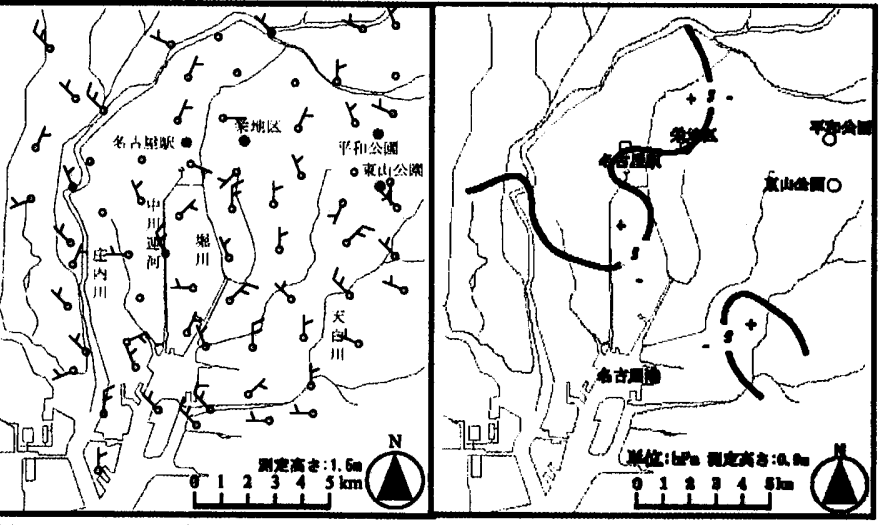

図32.風の分布

(2001年 2 月 13 日. 21 時)
图 33 ．水蒸気圧の分布 (2001年2月13日.21時)
したがって温度が低くなっていた。 $4{ }^{\circ} \mathrm{C}$ 以下の地域は庄内川の西 部と北部にあらわれた。海の存在と風の影響で南東部に相対的に 高温な地域が現れたと考えられる。

2）朝 4:00の風（図 35）庄内川流域と海岸部において北西寄りの 風が吹き、名古屋駅と栄を中心とした地域は北よりの穏やかな風 が吹いていた。東部の丘陵地帯は静穏である。

3）朝 4:00 の水蒸気圧（図 36）水蒸気圧は $3 \mathrm{hPa}$ から $5 \mathrm{hPa}$ のほぼ 一様な分布であった。東部の丘陵地帯と北東部において低く $4 \mathrm{hP}$ a 以下であった。

4) 日中の気温（図 37 ) 乾燥した冬の日の分布であった。1 $3{ }^{\circ} \mathrm{C}$ 以 上の気温域は東部丘陵の西側に南北に広がっている。海岸部や北 西部にも $13^{\circ} \mathrm{C}$ 以上の気温域があらわれた。東部丘陵の西側に現れ た $13{ }^{\circ} \mathrm{C}$ 以上の気温域は、都心の高温部が風に流されたと考えられ 


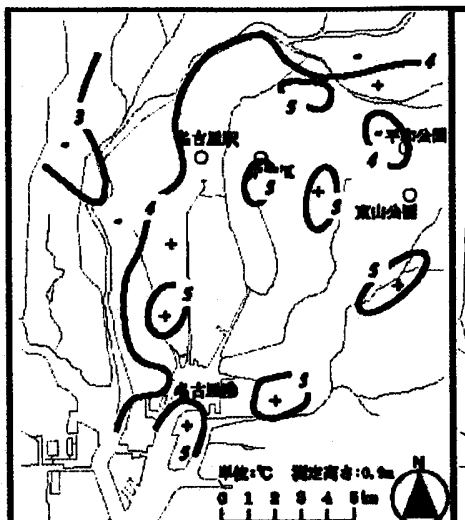

图34. 気温の分布

(2001年2月20日.4時)

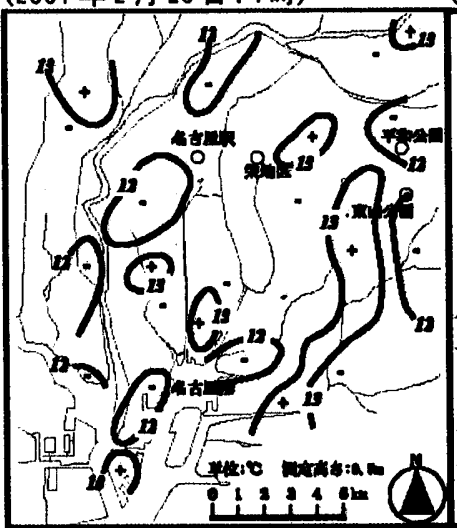

图37.気温の分布

(2001年2月20日.14 時)

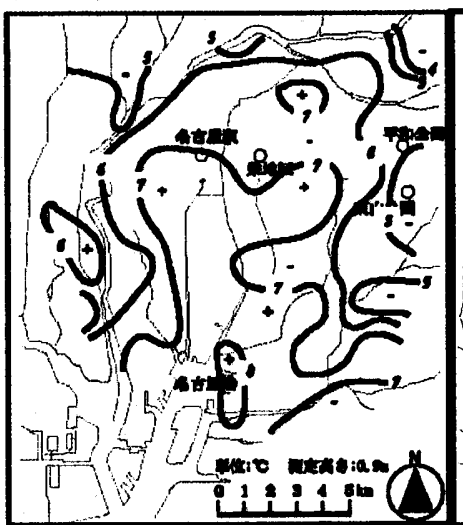

图 40.気温の分布

(2001年2月20日.21時)

\section{图 41. 風の分布}

(2001年2月20日.21時)
图38. 風の分布

(2001年2月20日.14 時)

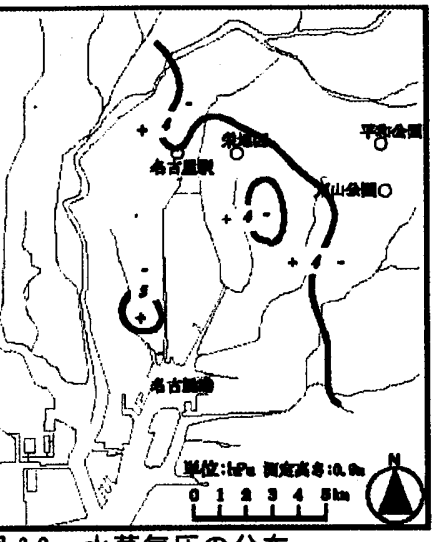

图 36 . 水蒸気压の分布

(2001年2月20日.4時)
る。冬季には、建築物の密集が日射を遮蔽してキャニオン内の昇 温が抑制され、平坦部で卓越風の風下側で日射が直接地表に入射 する地域や、人工排熱の多い地域は多少高温になると考えられ る。北西の季節風が卓越している時、高温域と低温域の差は約 1 ${ }^{\circ} \mathrm{C}$ 程度と考えられる。

5) 日中の風（図 38）庄内川流域と海岸部において北西の風が卓 越していた。栄を中心とした地域や東山公園の周辺は静穞であ る。しかしながら、朝や夜と比べて風が強く気温分布が小さく なったと考えられる。

6) 日中の水蒸気圧 (図 39) $3 \mathrm{hPa}$ 前後の一様な分布であった。

7）夜間の気温（図 40）風が静稳である冬の夜間の分布であった。 海岸部から都心部にかけて $7{ }^{\circ} \mathrm{C}$ 以上の地域が広がっていた。東部 丘陵や観測地域の北部などの海から距離のあり、都心部ではない 图 42 . 水蒸気圧の分布 (2001年2月20日.21時)

地域は $5{ }^{\circ} \mathrm{C}$ 以下の分布であっ た。

8）夜間の風（図 41）全域にお

いて静穏であった。

9）夜間の水蒸気圧（図 42）局 所的に $6 \mathrm{~h} \mathrm{~Pa}$ 以上の地域が観測 されたが、日中と同様 $5 \mathrm{hPa}$ 前後 の一様な分布であった。

\section{6. 考察}

大和田は夏季の典型的な夏 型気圧配置のもとでの濃尾平 野の風の流れは、日中は南よ りの海風によって占められ、 夜間になると海岸部と西側の 木曽 3 川沿いが南、および南 東の海風が吹き、三河山地で は山風が吹き始めること、さ らに、早朝となると海風の吹 走はほとんどみられず、山風 および陸風となることを指摘 ${ }^{4}$ している。本観測の夏季にお ける風の分布も大和田の指摘 と類似傾向を示している。冬 季においては西高東低の冬型 の気圧配置では北西の卓越風 が吹くことが多く、本観測に おいても北西の卓越風が認め られ、地表付近の観測点にも 上方風の影響が出ている傾向 があることが示されていると 考えられる。ただ、2月 20 日の 夜間に関しては、移動性高気 圧型に完全に移行し、ちょう ど高気圧の通過時であったた め静穏な状態が地上付近にも 反映されたと考えられる。ま

た、名古屋では商業施設が中区及び中村区、千種区西端に集中 し、工業地域は港区沿岸部及び南区の西端にある。上述以外の地

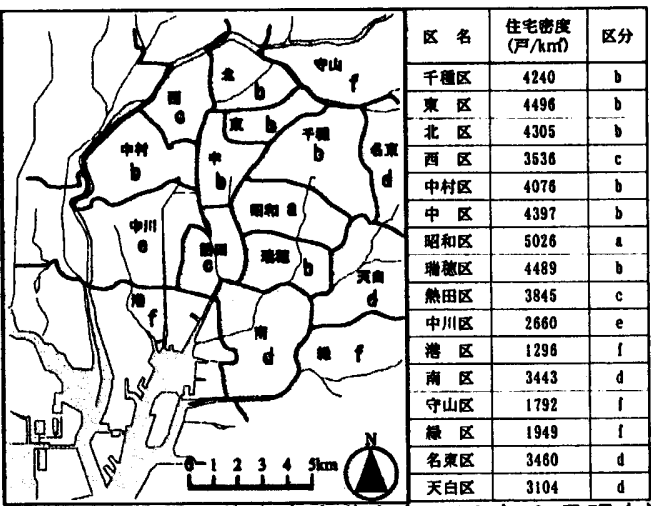

图 43. 名古屋の住宅需度分布 $(2000$ 年 8 月現在
域は近隣商業 地区を含めて ほぼ住宅地区 であるため考 察資料として 住宅密度を図 43 に示す。平 成 12 年 8 月か ら平成 13 年 8 月まで名古屋 市統計 ${ }^{12)}$ から 
作成した区別の住宅密度に顕著な変化は認められないため、平成 12 年 8 月時の数值を代表值とした。図は住宅密度を a から f まで の 6 段階評価に区分している。名古屋駅と栄の都心部やその東側 は住宅密度 a から b の高密度地区であり、東部丘陵地帯は $\mathrm{d}$ から $\mathrm{f}$ の相対的に低密度地区、西部は $\mathrm{c}$ であり、庄内川以西は $\mathrm{c} よ り ~$ 低密度であると考えられる。港湾部は住宅密度 e から f の低密度 であるが、比較的に工場が多く存在している。

以上の結果と気候分布を比較してみる。夏型（V型）及び西高 東低型（I 型）の気圧配置において早朝では、西部や東部丘陵地 帯は気温が低い(図 7.16.25)。港湾部や河川上は風が強く気温が 高く、名古屋駅から栄の都心部や山崎川中流部付近は風が弱く気 温が高い傾向がみられる(図 7.8.16.17.25.26.34.35)。西部は比 較的低層の住宅がまばらに立地し、裸地や耕地が存在する低地帯 である。東部丘陵は近年の宅地開発により減少したものの比較的 緑の多い地帯であるため気温が低く風が弱いと考えられる。港湾 部や河川上はオープンスペースであるため風が強く、陸地と水面 の熱容量の違いから気温が相対的に高いと推察される。名古屋駅 から栄の都心部は比較的高層の建物が林立し、風も弱いため畜熱 されるために、気温が高いと考えられる。山崎川中流付近は比較 的低層の住宅が密集した地域であり、大規模な緑地や河川から離 れているため風が弱く高温を示すものと考えられる。

夏型（V型）の気圧配置において日中（図10.11.19.20)では、 西部は気温が低く、港湾部や河川上は風が強く気温が低い。東部 丘陵地带は風が弱く、名古屋駅から栄の都心部や山崎川中流部付 近は風が弱く気温が高い。前述のように西部は裸地や耕地が存在 し建物も相対的に踈であり、港湾部や河川上はオープンスペース であり海風が吹走し、水面の温度もあまり上昇しないため気温が 相対的に低いと考えられる。東部丘陵地帯は港湾部や河川上とく らべるとそれほど気温が低くない。これは、観測点が路面上であ ること、宅地開発により大規模緑地が散在したこと、大和田の報 告 ${ }^{1)}$ にもあように夏季の南西風という西よりの成分を含んだ風 により、都市部の比較的温度の高い空気が丘陵際まで広がること があるためと考えられる。山崎川中流部付近は、西よりの成分を 含んだ風が名古屋港東側の工場地帯から流入し、海抜 $0 \mathrm{~m}$ 以下の 地域から $10 \sim 15 \mathrm{~m}$ の台地へのはじめに当たる変化点である。その 地形的影響や上記に述べた都市化の程度の影響により相対的に高 温を示すと考えられる。西高東低型（I 型）および冬季における 移動性高気圧型（III型）、の気圧配置において日中では、西部や港 湾部、河川上は風が強く、東部丘陵地帯や名古屋駅から栄の都心 部、山崎川中流部付近は風が弱いと考えられる(図 29.38 )。すな わち風の強い地域はオープンスペースの付近に生じやすい。しか しながら、分布図全域にわたり、北西風がみられる。2月13日、 20 日ともに名古屋地方気象台のデータでは、各日の卓越風向はと もに北西であり、日平均風速は $3.3 \mathrm{~m} / \mathrm{s} 、 3.5 \mathrm{~m} / \mathrm{s}$ であった。これは 上空風としての北西の季節風が地上にも反映されたものであり、 それ故に気温差があらわれにくくなったものと考えられる(図 28. 37)。

夏型（V型）の気圧配置において夜間では、比較的稳やかな南 よりの風が吹き、名古屋駅や栄などの都心部は静稳である( 図 $14.23)$ 。相対的に気温の高い地域は都心部であり、低い地域は東
部丘陵であり、ヒートアイランド強度は約 $2{ }^{\circ} \mathrm{C}$ 程度と考えられる (図 13.22)。西高東低型（I 型）の気圧配置において夜間では、北 西の卓越風が吹走している場合、それが地上付近にも反映され気 温、湿度ともに一様な分布となる(図 31.32 .33 )。冬季における移 動性高気圧型（III型）の気圧配置において夜間では、静穞である 場合、都心部および相対的に熱容量の大きい海の近くである海岸 部は気温が高く、地形的および都市的影響があらわれると考えら れる(図 40.41)。

\section{7. まとめ}

名古屋の市街地について、地表面付近の高さにおいての夏季 · 冬季における気候環境の実態報告、それらのデータをより汎用的 に位置づけるために、背景となる気圧配置の基づく総観気象場の 把握を行なった。加えて、気候分布の考察、住宅密度との比較考 察を行なった。以下にまとめを示す。

1) 夏型 ( V 型)、西高東低型（I 型）および冬季における移動 性高気圧型（III型）の気圧配置において早朝は西部や東部丘陵地 帯は気温が低く、港湾部や都心部は気温が高い。2 2 ) 夏型 $(\mathrm{V}$ 型）の気圧配置において日中では、海風が都心部付近まで吹込 み、西部や港湾部は気温が低く、都心部は気温が高い。3）西 高東低型（I 型）および冬季における移動性高気圧型（III型）の 気圧配置において日中では、強い北西風の影響から気温差は生じ にくい。4）夏型（V型）の気圧配置において夜間では、比較 的稳やかな南よりの風が吹き、東部丘陵地帯は気温が低く、都心 部は気温が高い。 5 ) 冬季における移動性高気圧型（III型）の 気圧配置において夜間では、風が静稳である場合、都心部や海岸 部は気温が高く、地形的および都市的影響があらわれる。

ヒートアイランドの存在は確認され住宅密度との関係も認めら れた。また、高温域の位置は風による影響を多少受けていると考 えられる。都心部における風は静稳である傾向が強く、水蒸気圧 は西部で高く東部で低い傾向がややみられる等、その他局所地域 による気候の違いも認められるが、今後、実測を重ね考察を必要 とすると考えられる。

\section{【謝辞】}

本研究を遂行するにあたり、実測にご尽力下さいました当時 の名古屋工業大学堀越研究室卒論生、及び大学院生の方々に感 謝の意を表します。

【引用文献】

1) 吉野正敏: 世界之日本の都市気候の変㟟と都市気候学の発達, 日本生気象学会雑誌第 27 巻 第 2 号, pp. 47-56、1990

2) 日本建築学会 (編著) : 都市環境のクリマアトラスー気候情報を活かした都市づくりー, ぎよ うせい, 2000

3）大和田道雄 : 名古屋の気候環境，荘人社，1980

4) 大和田道雄 : 伊勢湾岸の大気墂境, 名古屋大学出版会, 1994

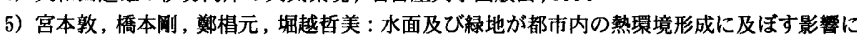
関する研究, 日本建築学会大会学術講演梗概集 D-1, pp. 575-576, 1995

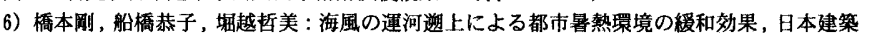
学会計画系論文集 第 545 号, pp. 65-70, 2001

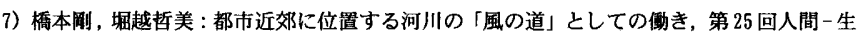
活環境系シンポジウム研究報告集, pp. 39-42, 2001

8）向井要，凮越折美：名古屋市中川運河における海風遡上が体感気候に及ほす影整，日本建 築学会計画系論文集 第 553 号, pp. 37-41, 2002

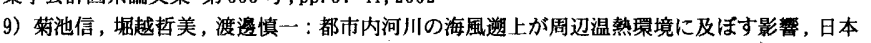
建築学会大会学術講演梗概集 D-1, pp. 617-618, 2000

10）牛山素行（編）: 身近な気象・気候調㭗の基礎，古今書院，2000

11) 吉野正敏, 福岡義隆 : 半旬別の気压配置こよみ, 天気 14, pp. 10-15, 1967

12）名古屋市総務局企画部統計課：統計なこやや Web 版名古屋市統計年垀平成 14 年版, 名古 屋市, 2003

(2004年 8 月 13 日原稿受理，2005年 6 月 15 日採用決定） 